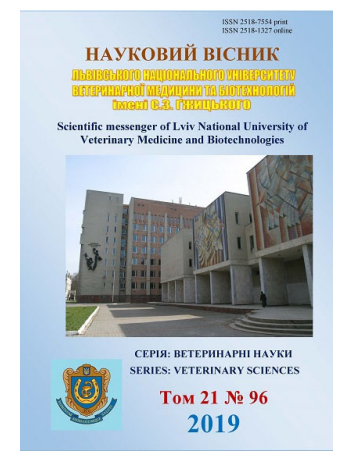

\author{
Науковий вісник Львівського національного університету \\ ветеринарної медицини та біотехнологій імені С.3. Гжицького. \\ Серія: Ветеринарні науки
}
Scientific Messenger of Lviv National University of Veterinary Medicine and Biotechnologies. Series: Veterinary sciences

UDC 619:616.381-002:636.8

\title{
Pathomorphology of cats with myocardial infectious peritonitis
}

\author{
G.I. Kotsyumbas, M.R. Khalaniia
}

Stepan Gzhytskyi National University of Veterinary Medicine and Biotechnologies Lviv, Ukraine

Article info

Received 06.11.2019

Received in revised form 12.12 .2019

Accepted 13.12.2019

Stepan Gzhytskyi National University of Veterinary Medicine and Biotechnologies Lviv, Pekarska Str., 50, Lviv, 79010, Ukraine. Tel.: +38-032-260-28-89 E-mail: galyna.kotsyumbas@gmail.com
Kotsyumbas, G.I., \& Khalaniia, M.R. (2019). Pathomorphology of cats with myocardial infectious peritonitis. Scientific Messenger of Lviv National University of Veterinary Medicine and Biotechnologies. Series: Veterinary sciences, 21(96), 177-184. doi: 10.32718/nvlvet9631

The article presents the results of macroscopic and microscopic examinations of myocardial cats in wet and mixed forms of FIP. A pathoanatomical study of 19 cat carcasses, aged from 3 months to 7 years, was diagnosed with infectious peritonitis during life (on the basis of anamnesis, clinical features, morphological and biochemical blood test, ultrasound, Rivalt test and FCVetx rapid test VetE.) All animals were kept at home. For the microstructural study, samples of cats' hearts were selected, which were fixed in $10 \%$ aqueous formalin neutral solution, Carnua, Buen solutions and $96^{\circ}$ ethyl alcohol. Histogram sections were stained with hematoxylin and eosin staining, picrofuxin (Van Gizon), PAS reaction (McManus), methyl green pyronin (Brache), Malory, and examined under a microscope. Histological examination of the cardiac muscle of cats in various forms of infectious peritonitis revealed changes of non-inflammatory and inflammatory nature. In the exudative form, non-inflammatory processes prevailed. In the myocardium, the most severe changes occurred in the capillaries, the walls of the arterial vessels and the stroma, which were characterized by diapedic hemorrhage, mucoid and fibrinoid swelling and necrosis of the walls of the arterioles. Disorganization of connective tissue was accompanied by stratification of connective tissue fibers and impregnation of weakly oxyphilic, PAS-positive compounds of the intermuscular lumen, which was combined with dystrophic changes in cardiomyocytes. In the mixed form, proliferative-destructive vasculitis, diffuse or focal lymphoid-histiocytic infiltrates in the myocardium prevail. The revealed optical changes in the structural elements of the heart indicated a sharp weakening of the contractile function of cardiomyocytes and heart failure. In addition, it should be noted that the characteristic morphological manifestation for immunocomplex diseases is the development of vasculitis, which is preceded by fibrinoid necrosis of the walls of the arterial vessels and intensive infiltration of their circulatory elements, and these changes occurred in infectious peritonitis of cats.

Key words: cats, infectious peritonitis, FIP, heart, myocardium, cardiomyocytes, histological changes.

\section{Патоморфологія міокарду котів за інфекційного перитоніту}

\author{
Г.І. Коцюмбас, М.Р. Халанія
}

Львівський національний університет ветеринарної медицини та біотехнологій імені С.3. Гжиџького, м. Львів, Україна

У статті представлені результати макроскопічних та мікроскопічних досліджень міокарда котів за вологої $і$ змішаної форм FIP. Проведено патологоанатомічне дослідження 19 трупів котів, віком від 3 місячів до 7 років, у яких прижиттєво було діагностовано інфекиійний перитоніт (на основі анамнезу, клінічних ознак, морфологічного та біохімічного аналізу крові, ультразвукової діагностики, тесту Рівальта та експрес-тесту VetExpert FCoV). Усі тварини утримувалися в домашніх умовах. Для мікроструктурного дослідження відібрано взіриі серця котів, які фіксували в 10\% водному розчині нейтрального формаліну, розчинах Карнуа, Буена та $96^{\circ}$ етиловому спирті. Виготовляли гістозрізи, які фарбували гематоксиліном та еозином, пікрофуксином (Ван-Гізон), PAS-реакція (Мак-Манусом), метиловим зеленим-піроніном (Браше), Малорі, і вивчали під мікроскопом. За гістологічного дослідження серцевого м'яза котів за різних форм інфекційного перитоніту встановлено зміни незапального та запального характеру. За ексудативної форми превалювали процеси незапального характеру. У міокарді найважчі зміни перебігали в капілярах, стінках 
артеріальних судин та стромі, які характеризувались діапедезними крововиливами, мукоїдним та фібриноїдним набуханням $і$ некрозом стінок артеріол. Дезорганізація сполучної тканини супроводжувалась розшаруванням сполучнотканинних волокон та просяканням їх слабооксифільними, РАS-позитивними сполуками міжм'язових просвітів, щуо поєднувалось із дистрофічними змінами в кардіоміоцитах. За змішаної форми - превалювали проліферативно-деструктивні васкуліти, дифузні або фокальні лімфоїдно-гістіочитарні інфільтрати у міокарді. Виявлені світлооптично зміни в структурних елементах серия вказували на різке послаблення скорочувальної функиії кардіоміочитів та серцеву недостатність. Крім того, необхідно відзначити, щзо характерним морфологічним проявом для імунокомплексних захворювань є розвиток васкулітів, яким передують фібриноїдний некроз стінок артеріальних судин та інтенсивна інфільтраџія їх круглоклітинними елементами і саме такі зміни мали місце за інфекційного перитоніту котів.

Ключові слова: коти, інфекиійний перитоніт, FIP, серцее, міокард, кардіоміоцити, гістологічні зміни.

\section{Вступ}

Інфекційний перитоніт котів (FIP) - імунноопосередковане захворювання домашніх та диких котів, зумовлене вірулентним котячим коронавірусом, що спричиняс загибель молодих котів, а також ставить під загрозу утримуваних в неволі вимираючих диких кішок (Baydar et al., 2014; Kim et al., 2016; Ziółkowska et al., 2017). Збудник - вірус FIP (FIPV) це моноцитарний / макрофаго-тропний / мутований вірус кишкового коронавірусу котів (FECV), який спричиняє в організмі тварин виражену запальну реакцію (Brown, 2011; Kipar \& Meli, 2014; Pedersen et al., 2016; Khalaniia et al., 2018).

На сьогоднішній день FIP залишається однією 3 невиліковних захворювань. Дане захворювання характеризується довгим інкубаційним періодом, не має виражених симптомів на початкових етапах розвитку FIP, не до кінця 3'ясований патогенез захворювання, не визначена ланка розвитку хвороботворних процесів в організмі (Knotek et al., 2000; Pedersen, 2014a; Pedersen, 2014b).

У доступній літературі відносно мало публікації щодо висвітлення патологоанатомічних змін внутрішніх органів за FIP, та ще менше щодо гістологічних та гістохімічних змін в органах і тканинах. Що стосується патоморфології серця, то в деяких публікаціях згадується, що у хворих котів деколи може розвиватись гідроперикард або серозний перикардит, а за мікроструктурних змін в органі повідомлення поодинокі та недостатньо описані (Kipar et al., 2005; Fischer et al., 2012; Han et al., 2014; Oliverira et al., 2014; Rolim et al., 2016; Galatjuk et al., 2016; Crawford et al., 2017; Günther et al., 2018; Ernandes et al., 2019). Зважаючи на це, актуальним $є$ 3'ясування морфо-гістохімічних змін в органах і тканинах, зокрема у серці хворих на інфекційний перитоніт котів, оскільки це допоможе зрозуміти причини розвитку клінічних симптомів та внесе деякі доповнення в патоморфологію.

Метою роботи було вивчити патологоанатомічні, гістологічні та гістохімічні зміни в серці котів за вологої та змішаної форм FIP.

\section{Матеріал і методи досліджень}

Патоморфологічні дослідження проводили на кафедрі нормальної та патологічної морфології і судової ветеринарії ЛНУВМБ імені С.З. Гжицького та кафедрі патології Вроцлавського природничого університету (Республіка Польща) протягом 2016-2019 років. Проведено патологоанатомічне дослідження 19 трупів котів, віком від 3 місяців до 7 років, у яких прижиттево діагностовано FIP (на основі анамнезу, клінічних ознак, лабораторно-інструментальних методів дослідження та експрес-діагностики (експрес-тест VetExpert FCoV).

Для гістологічного та гістохімічного дослідження було відібрано фрагменти тканин серця, які фіксували у $10 \%$ водному розчині нейтрального формаліну, розчинах Карнуа, Буена та $96^{\circ}$ етиловому спирті. Виготовляли гістозрізи, які фарбували гематоксиліном та еозином, пікрофуксином (Ван-Гізон), PAS-реакція (Мак-Манусом), метиловим зеленим-піроніном (Браше), Малорі, і вивчали під мікроскопом (Pyrs, 1962; Merkulov, 1969; Goral's'kyj et al., 2005; Pishak, 2008). Готові гістопрепарати розглядали під світловим мікроскопом Leica DM-2500 (Switzerland), фотографували їх фотокамерою Leica DFC450C 3 програмним забезпеченням Leica Application Suite Version 4.4.

\section{Результати та їх обговорення}

Серце котів переважно конусоподібної форми. У котів, які загинули від вологої форми у більшості випадках епікард прозорий, вологий, міокард світлочервоного кольору, на розрізі в'ялої консистенції. У деяких особин під епікардом виявляли дрібні крапкові крововиливи. У котів, які загинули від змішаної форми серце сірувато-фіолетового відтінку, місцями епікард потовщений, склеротизований. Міокард в ділянках розміщення коронарних судин світло-сірого забарвлення, ущільнений (рис. 1).

За гістологічного дослідження в міокарді котів виявляли яскраво виражені зміни в судинній системі, які супроводжувались порушенням структурнофункціонального стану самої паренхіми органу. Слід зазначити, що найважчі зміни розвивались у гемоциркуляторній системі, а особливо в стінках артеріальних кровоносних судин, а також у венозній системі і мікросудинах як за вологої так і за змішаної форми. За ексудативної форми виявляли сильне розширення просвіту артеріол і вен, що супроводжувалось значною деструкцією ї стінок. Цитоплазма ендетолію піддавалась вакуолізації. В одних особин в просвіті судин відсутні форменні елементи крові, але наявна дрібнозерниста PAS-позитивна білкова маса (рис. 2). 


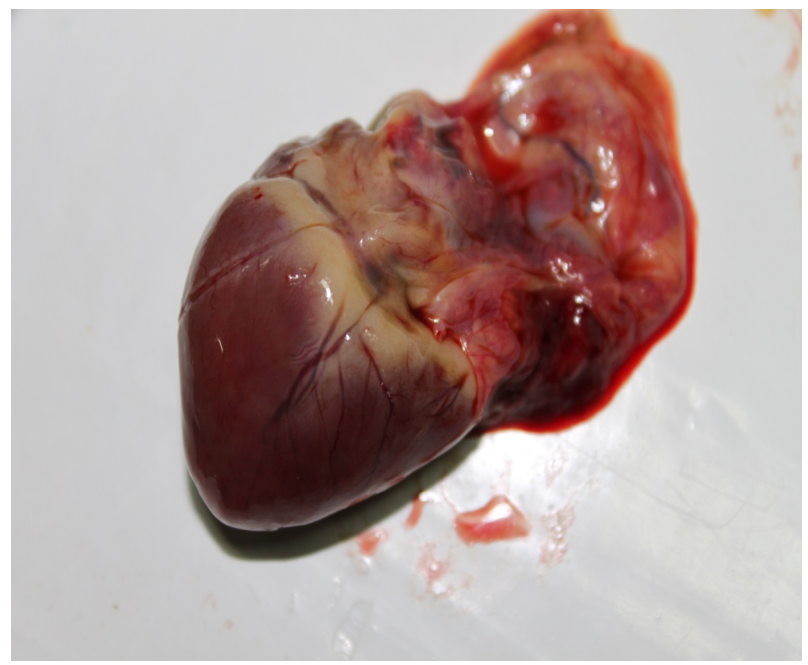

$a$

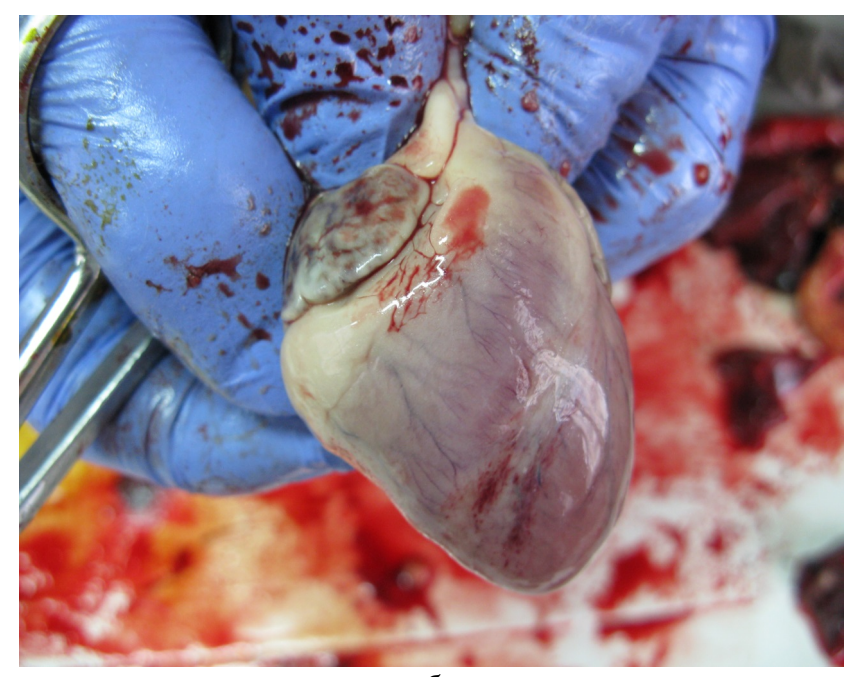

$\sigma$

Рис. 1. Серце кота за вологої (а) та змішаної (б) форм

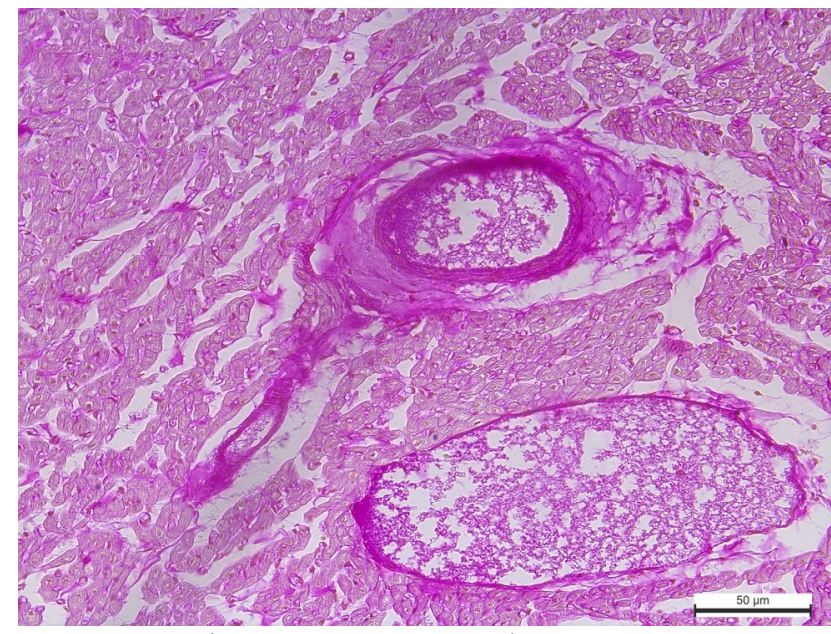

Рис. 2. Міокард. Вазодилатація. PAS-позитивна білкова маса у просвіті судин. Мак-Манус Ок.10, об. 20

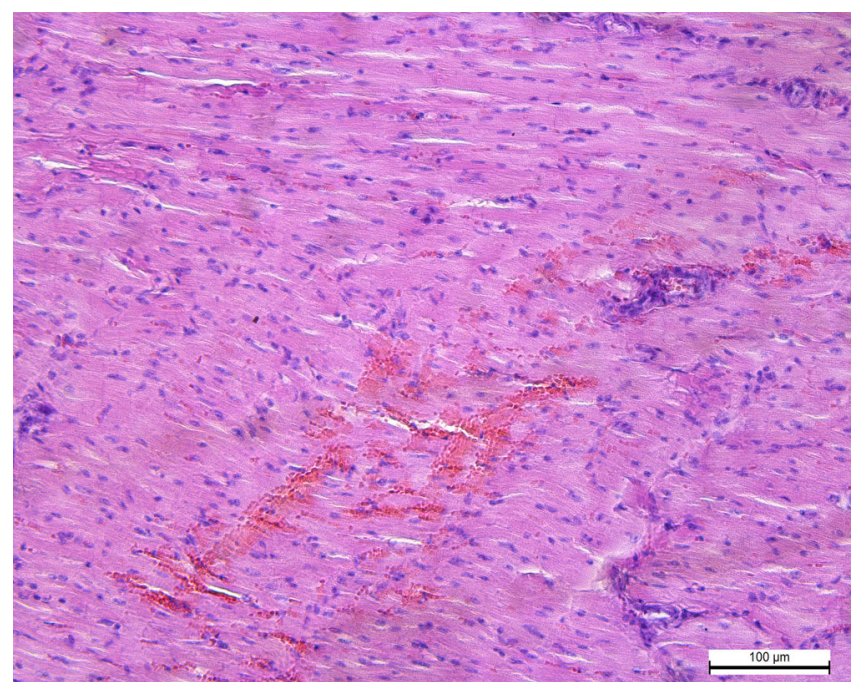

Рис. 4. Серце. Діапедезні крововиливи. Гематоксилін та еозин. Ок. 10 , об. 20

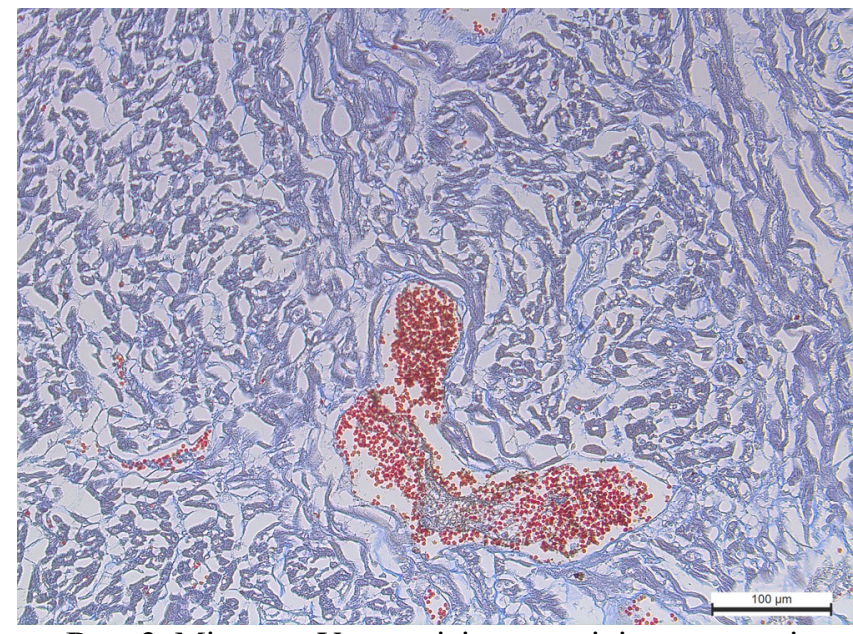

Рис. 3. Міокард. У просвіті судин сірі волокнисті структури фібрину. Малорі. Ок.10, об. 20

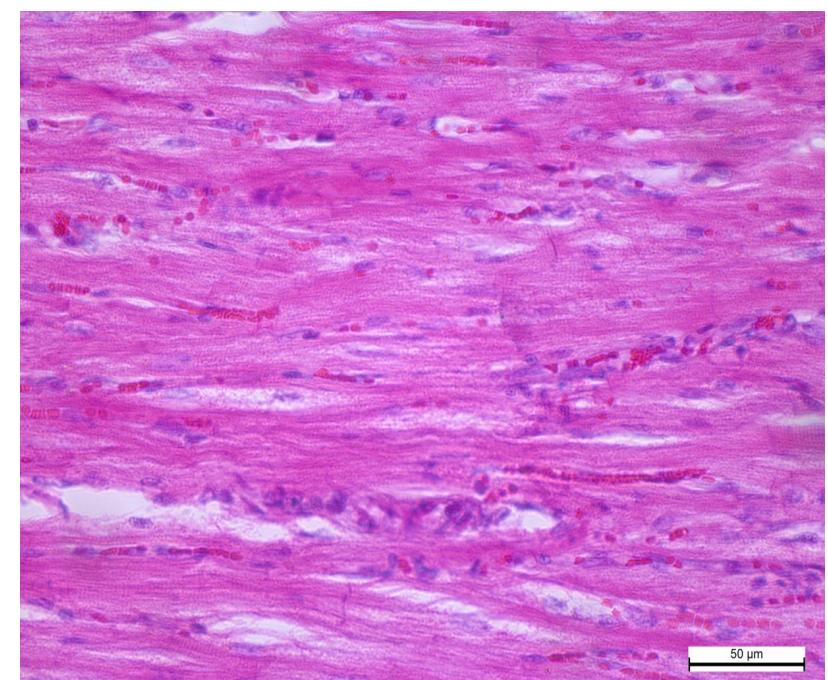

Рис. 5. Серце. Міжм’язові простори просочені слабооксифільною рідиною. Агрегація еритроцитів у капілярах. Гематоксилін та еозин. Ок.10, об. 40 
В інших особин у просвіті венозних судин виявляли серед еритроцитів сірі переплетені волоконця фібрину, що вказувало на розвиток дисемінованого тромбозу (рис. 3). Виявлені морфологічні зміни в судинній системі вказували на різке порушення як фізикохімічного складу крові так і реології.

У мікросудинах виявляли набухання ендотеліальних клітин. Ядра ендотелію міхурцеподібної форми або пікнотизовані. Відзначалась десквамація ендотелію та агрегація еритроцитів. Разом 3 тим в деяких особин візуалізувались діапедезні еритроцитарні інфільтрати, що вказувало на порушення стінок капілярів (рис. 4). На тлі гемодинамічних порушень мікроциркуляторного русла у міокарді наростала гіпоксія, розвивалась деполімеризація несульфатованих глікозаміногліканів стінок та міжваскулярної сполучної тканини, що відобразилось дезорганізацією сполучної тканини, розшаруванням м'язових волокон. Порушення рівноваги між проникністю гістогематогенного бар'єру і функцією дренажних систем, морфологічно проявилось просяканням міжм'язових просвітів слабооксифільною рідиною та адгезією еритроцитів у капілярній сітці. У таких ділянках кардіоміоцити набухлі, їх контури розмиті, поперечна посмугованість ретушована. Ядра кардіоміцитів деформовані, в одних волокнах збільшені, з низьким вмістом хрома-

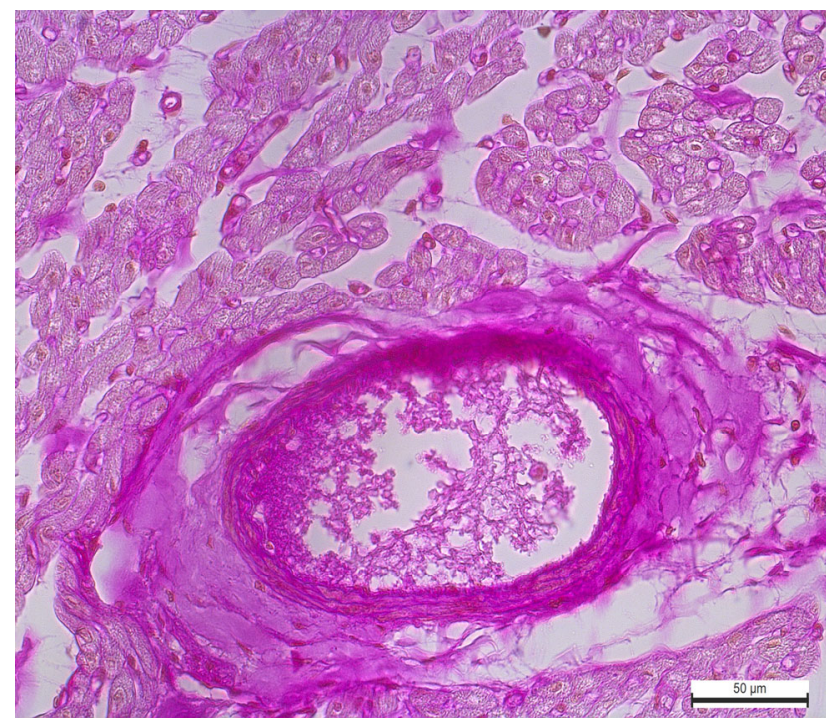

Рис. 6. Артеріола міокарда кота за вологої форми. Розшарування еластичних та аргірофільних волокон артеріол, просякання їх PAS-позитивними білками. Мак-Манус. Ок.10, об. 40

Виявлені зміни вказували не тільки на підвищене гемодинамічне навантаження на коронарні судини, що скоріше всього зумовлене стенозом легеневих артерій, а також ймовірним впливом самого інфекційного чинника на стінки судин. Зрозуміло, що зміни в судинній системі стало морфологічним субстратом розвитку серцевої недостатності та відобразилось порушеннями структури кардіоміоцитів. Дезорганізація сполучної тканини, набряк, розшарування сполуч- тину, слабо забарвлені, в інших пікнотизовані або лізовані (рис. 5).

Яскраво виражені структурні зміни превалювали в стінках артеріол. Мікрорельєф внутрішньої еластичної мембрани артеріол порушений. В одних особин еластична мембрана потовщувалась, розпадалась на тоненькі волоконця, а в інших навпаки витончувалась, ставали дрібноскладчастою. На препаратах, забарвлених за Мак-Манусом у стінках артеріол та дрібних артеріальних судинах виражене різке розшарування еластичних та аргірофільних волокон, їх дезорганізація та розпад. Адвентеціальний простір розширений, просочений плазмовими білками, багатим PASпозитивними речовинами. У патологічний процес втягнуті і гладком'язові волокна м'язової оболонки артеріол. Вони набухлі, просочені глікопротеїдами, їх ядра часто лізовані та пікнотичні (рис. 6). Виявлені зміни в стінках артеріол вказують на розвиток фібриноїдного некрозу. На препаратах, забарвлених за ВанГізон в стінках артеріальних судин проглядались аналогічно змінені з втраченою фібрилярністю, гомогенною структурою волокна в стані розпаду. При цьому світлооптично візуалізувалось також відшарування ендотеліального шару, а в просвіті судин павутиноподібна білкова маса (рис. 7).

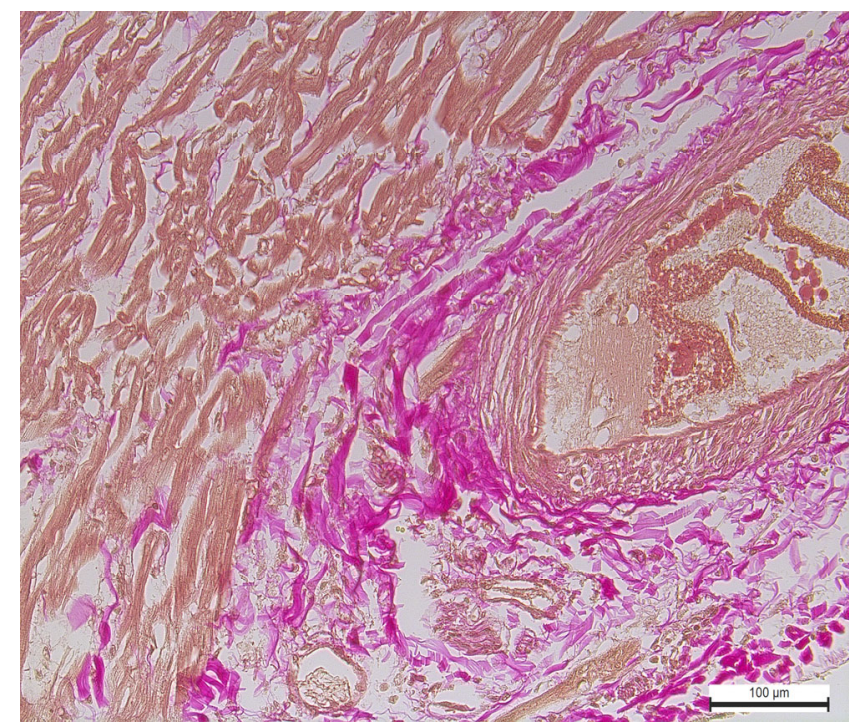

Рис. 7. Міокард. Артеріальна судина. Відшарування ендотеліального пласту. Розпушення еластичних та аргірофільних волокон. Ван-Гізон. Ок.10, об. 20

нотканинних волокон та просякання слабооксифільною масою міжм'язових просвітів супроводжувалось дистрофічними процесами в самих кардіоміоцитах. На препаратах, забарвлених за Мак-Манусом відзначали нагромадження фуксинофільної маси у міжм'язових просвітах міокарда (рис. 8) У таких ділянках кардіоміоцити набухлі, втрачали поперечну посмугованість, саркоплазма слабо вбирала фарбу (рис. 9). 


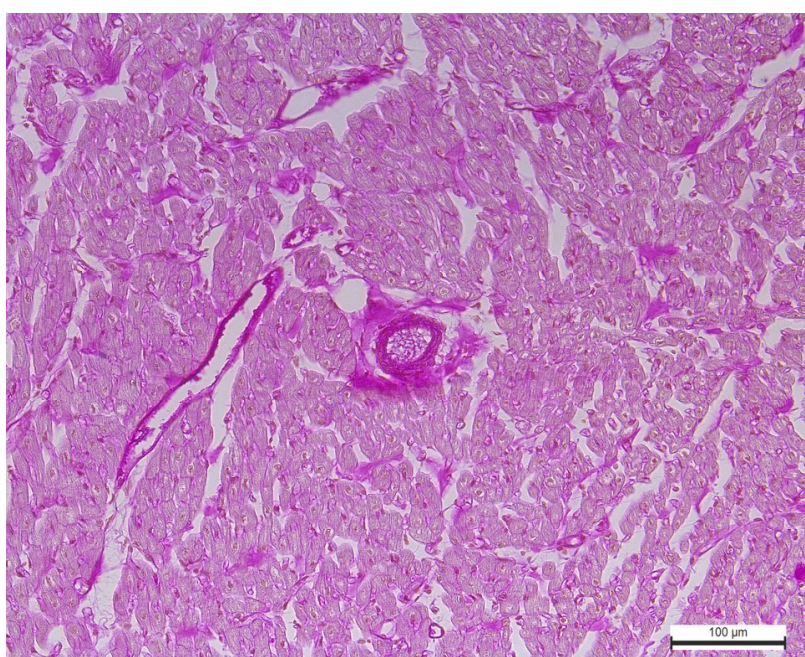

Рис. 8. Міокард. Міжм’язові простори, строма, стінки судин просякнуті фуксинофільною рідиною.

Мак-Манус. Ок.10, об. 20

Переважно у периваскулярній зоні, кардіоміоцити знаходились в стані зернистої дистрофії, міоцитолізу. У змінених м'язових волокон ядра набубнявілі, деформовані, 3 малим вмістом хроматину. Розвиток таких змін в кардіоміоцитах зумовлено в першу чергу гіпоксією, яка призводить до ацидозу, активації лізосомальних ферментів, нагромадження продуктів гідролізу, підвищення осмотичного тиску. Гістохімічно на пре-

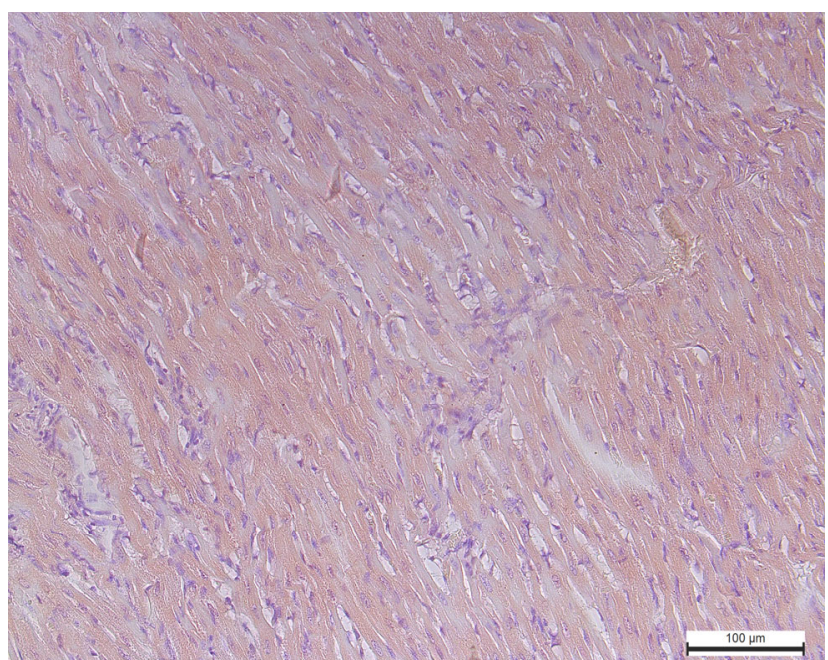

Рис. 9. Міокард. Осередки кардіоміоцитів в стані зернистої дистрофії. Гематоксилін та еозин. Ок. 10, об. 20

паратах, забарвлених за Браше цитоплазма кардіоміоцитів не вбирала піронін, що вказує на різке зниження в них як білоксинтезуючої так і скорочувальної функції м'язових волокон серця. Разом з тим ядра м'язових волокон погано вбирали метиленовий синій, а в деяких набухлих волокнах ядра взагалі не визначались, що свідчило про їх лізис і прогресування некробіотичних процесів (рис. 10).
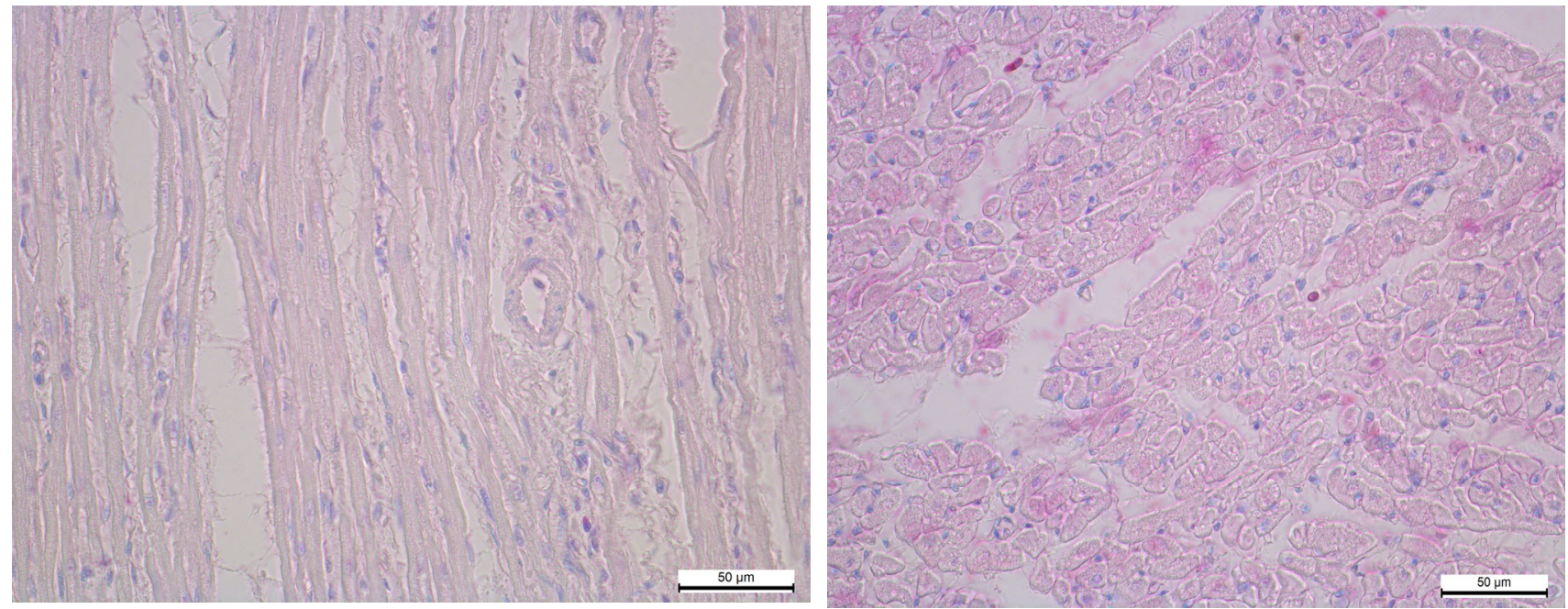

Рис. 10. Міокард. Різке зниження піронінофільності у кардіоміоцитах. Браше. Ок.10, об. 40

У котів, які загинули від змішаної форми FIP зміни в стінках судин та серцевому м'язі характеризувались розвитком запальних процесів. У стінках артеріол окрім набряку, плазматичного просякання та фібриноїдних змін відзначали в адвентиціальному шарі яскраво виражені реактивні процеси, інфільтрацію даної ділянки макрофагами, лімфоцитами. Переважно в навколо судинній зоні траплялись в одних випадках помірні, в інших - більш потужні клітинні інфільтрати, що вказує на розвиток артериїтів, ймовірно зумовлене імунним запаленням. Цитоплазма ендотеліальних клітин внутрішньої оболонки артеріол набухла, клітини часто десквамовані (рис. 11 a, б). Треба зазна- чити, що просвіт артеріол різко розширений, однак формені елементи крові в них відсутні. Структура м'язових волокон порушена: міжм'язові просвіти розширені, більшість кардіоміоцитів атрофовані, їх ядра пікнотичні.

Відомо, що тривала персистенція антигену зумовлює імунну відповідь, що веде до утворення антитіл, внаслідок чого утворюються комплекси антигенантитіло. Циркулюючі імунні комплекси осідають на стінках кровоносних судин, що призводить до ушкодження в першу чергу судин, а потім як наслідок тканин. 


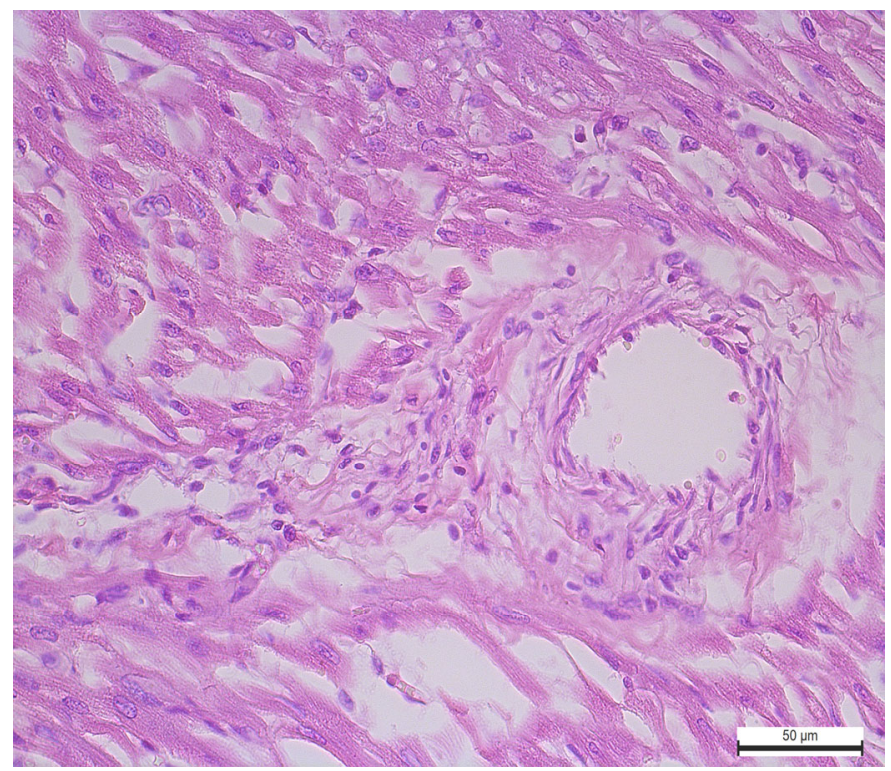

A

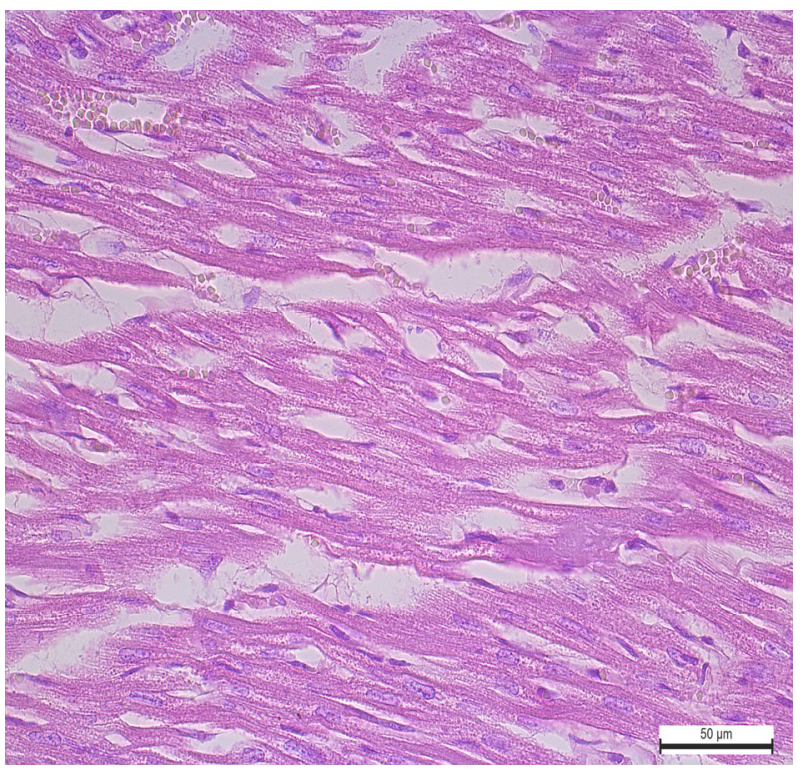

Б

Рис. 11. Міокард. А - Периваскулярні клітинні інфільтрати. Б - Порушення структури кардіоміоцитів.

Гематоксилін та еозин. Ок. 10, об. 40

Тому основним морфологічним проявом імунокомлексного ураження є васкуліти, яким передують мукоїдне, фібриноїдне набухання судин та їх фібриноїдний некроз.

У серці хворих котів, васкуліти супроводжувались інфільтрацією навкололежачої інтерстиції лімфоцитами, гістіоцитами, розвитком гіпоксичного стану та порушенням метаболізму і структури кардіоміоцитів. Разом 3 тим утворення клітинних інфільтратів навколо судин вело до атрофічних процесів та деструкцією кардіоміоцитів. Відбувалось розшарування та утворення світлих прошарків між каріоміоцитами (рис 11

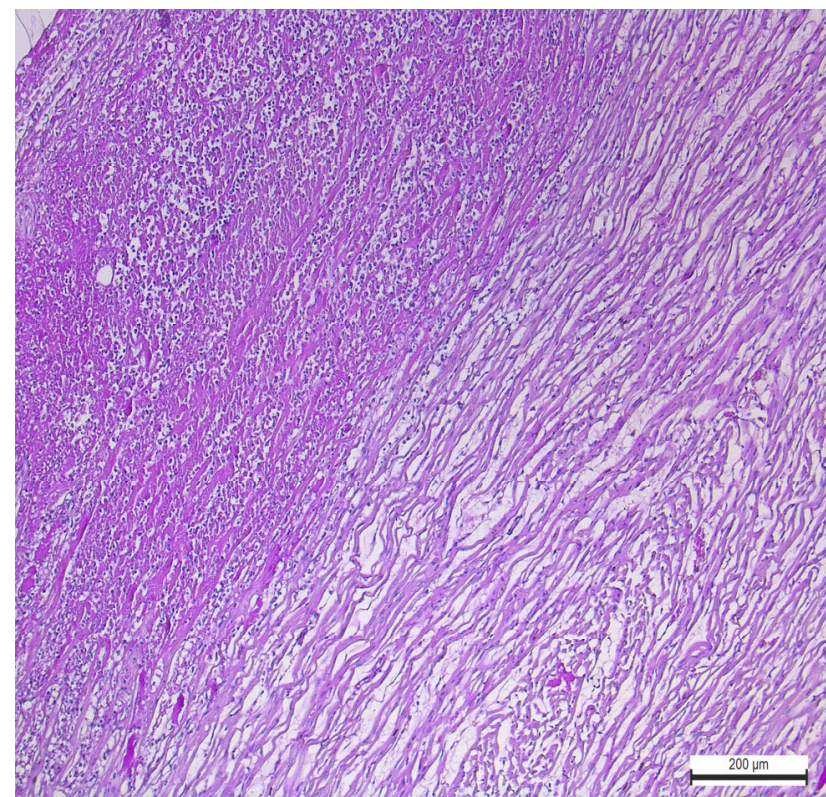

Мак-Манус. Ок. 10, об. 10 б). Крім того за змішаної форми в стінці лівого шлуночка міокарда траплялись осередки запальних інфільтратів у вигляді дифузних та вогнищевих клітинних скупчень. Найчастіше у субепікардіальній ділянці стінки міокарду лівого шлуночка виявляли дезорганізацію кардіоміоцитів, їх розшарування та інфільтрацію круглоклітинними елементами.

Прогресувала в кардіоміоцитах в осередках клітинної інфільтрації внутрішньоклітинна дезорганізація міофібрил, їх витончення та розрив і просякання PAS-позитивними речовинами. Ядра кардіоміоцитів пікноформні (рис. 12).

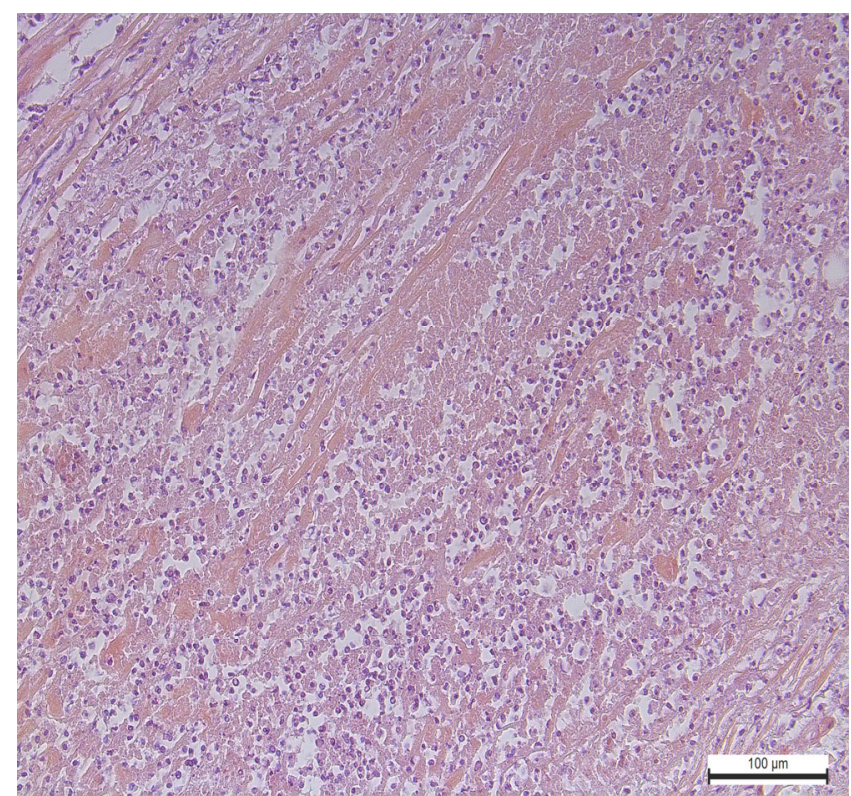

Гематоксилін та еозин. Ок. 10, об. 20

Рис. 12. Міокард кота за змішаної форми. Дезорганізація кардіоміоцитів, їх розшарування та інфільтрація круглоклітинними елементами у субепікардіальній ділянці. 


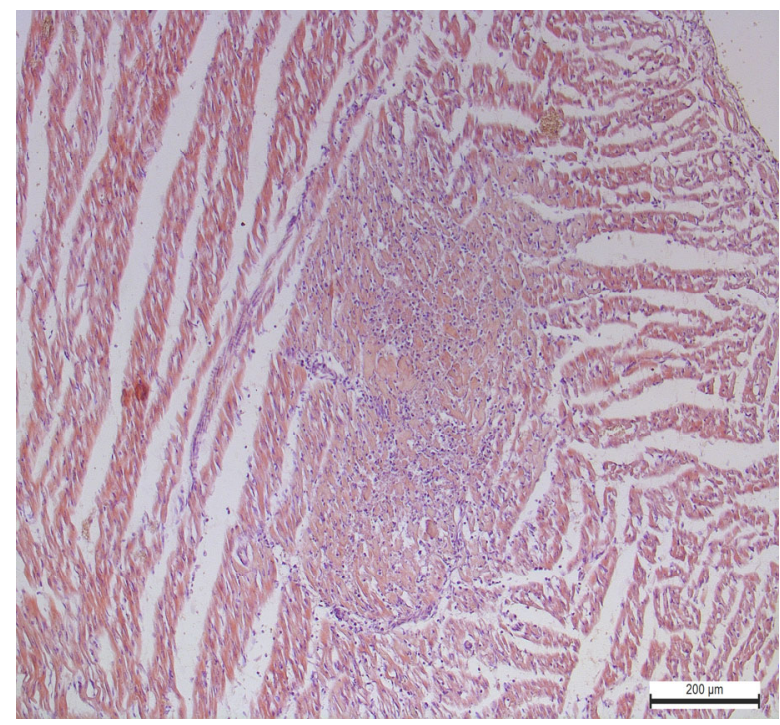

A

Гематоксилін та еозин. ок.10, об. 10

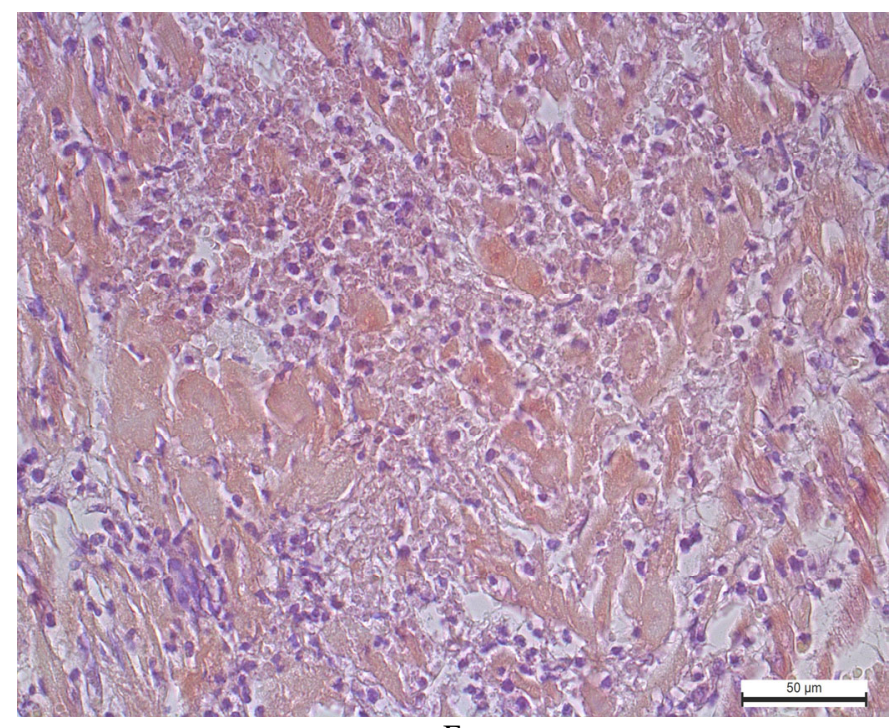

Б

Рис. 13. Міокард кота за змішаної форми. А - Осередки клітинних інфільтратів. Б - Фрагментовані кардіоміоцити, в стані некробіозу

У інших особин виявляли в лівому шлуночку серця обмежені круглоклітинні осередки. В ділянках інтенсивної інфільтрації гістіоцитами та лімфоцитами, превалював розпад міофібрил, коагуляційний міоцитоліз, фрагментація. М'язові волокна проглядались у вигляді набухлих дрібних фрагментів та дрібнозернистої еозинофільної білкової маси, внаслідок літичних і некротичних процесів в кардіоміоцитах (рис. 13).

Аналізуючи морфологічні зміни в серці слід відзначити, що найважчі процеси перебігали в стінках артеріол та артерій середнього калібру і характеризувались за вологої форми - дезорганізацією їх стінок, підвищеною проникністю, діапедезними крововиливами, мукоїд ним та фібриноїдним набуханням і некрозом стінок артеріол, а за змішаної форми - превалювали проліферативно-деструктивні васкуліти, дифузні або фокальні лімфоїдно-гістіоцитарні інфільтрати у міокарді. Виявлені світлооптично зміни в структурних елементах серця вказували на різке послаблення скорочувальної функції серця та серцеву недостатність. Крім того необхідно відзначити, що прогресування васкулітів, яким передували фібриноїдний некроз стінок артеріальних судин та інтенсивна інфільтрація їх круглоклітинними елементами є характерним морфологічним проявом для імунокомплексних захворювань, що мало місце за FIP.

\section{Висновки}

1. У серці котів за вологої форми FIP встановлено діапедезні крововиливи, мукоїдне та фібриноїдне набухання і некроз стінок артеріол, що поєднувалось iз дистрофічними змінами в кардіоміоцитах, набряком, розпушенням і просякання PAS-позитивними сполуками строми органу.
2. У котів за змішаної форми у серці превалювали проліферативно-деструктивні васкуліти і дифузні або фокальні лімфоїдно-гістіоцитарні інфільтрати.

Перспективи подальших досліджень. У перспективі будуть продовжені дослідження гістологічних та гістохімічних змін внутрішніх органів за різних форм FIP.

\section{References}

Baydar, E., Eröksüx, Y., \& Timurkan, M.O. (2014). Feline infectious peritonitis with distinct ocular involvement in a cat in Turkey. Kafkas Univ Vet Fak Derg, 20(6), 961-965. doi: 10.9775/kvfd.2014.11195.

Brown, M. A. (2011). Genetic determinants of pathogenesis by feline infectious peritonitis virus. Veterinary Immunology and Immunopathology, 143(3-4), 265268. doi: 10.1016/j.vetimm.2011.06.021.

Crawford, A.H., Stoll, A.L., Sanchez-Masian, D., Shea, A., Michaels, J., Fraser, A.R., \& Beltran, E. (2017). Clinicopathologic Features and Magnetic Resonance Imaging Findings in 24 Cats with Histopathologically Confirmed Neurologic Feline Infectious Peritonitis. Journal of Veterinary Internal Medicine, 31(5), 14771486. doi: 10.1111/jvim.14791.

Ernandes, M., Cantoni, A., Armando, F., Corradi, A., Ressel, L., \& Tamborini, A. (2019). Feline coronavirusassociated myocarditis in a domestic longhair cat. Journal of Feline Medicine and Surgery Open Reports, 5(2), 2055116919879256. doi: 10.1177/2055116919879256.

Fischer Y., Wess, G., \& Hartmann, K. (2012). Pericardial effusion in a cat with feline infectious peritonitis. Schweiz Arch Tierheilkd, 154(1), 27-31. doi: 10.1024/0036-7281/a000289.

Galatjuk, O.Je., Peredera, O.O., Lavrinenko, I.V., \& Zhernosik, I.A. (2016). Infektsijni hvoroby kotiv. Navchal'nij posibnyk dlja vuziv II-IV rivniv akredytacii'. Zhytomyr: "Polissja" (in Ukrainian). 
Golub, R., Tan, J., Watanabe, T., \& Brendolan, A. (2018). Origin and Immunological Functions of Spleen Stromal Cells. Trends in Immunology, 39(6), 503-514. doi: 10.1016/j.it.2018.02.007.

Goral's'kyj, L.P., Homych, V.T., \& Konons'kyj, O.I. (2005). Osnovy gistologichnoi' tehniky i morfofunkcional'ni metody doslidzhen' $\mathrm{u}$ normi ta pry patologii' [Bases of histological technology and morphofunctional methods of research in norm and in pathology]. Polissja, Zhytomyr (in Ukrainian).

Günther, S., Felten, S., Wess, G., Hartmann, K., \& Weber, K. (2018). Detection of feline Coronavirus in effusions of cats with and without feline infectious peritonitis using loop-mediated isothermal amplification. Journal of Virological Methods, 256, 32-36. doi: 10.1016/j.jviromet.2018.03.003.

Han, J.-I., Kang, S.-Y., Yoon, K.-J., \& Na, K.-J. (2014). Nucleic acid-based differential diagnostic assays for feline coronavirus. Journal of Virological Methods, 208, 21-25. doi: 10.1016/j.jviromet.2014.07.013.

Khalaniia, M.R., Kotsyumbas, G.I., \& Pritsak, V.V. (2018). Pathomorphology of peripheral organs of immunogenesis in cats with spontaneous feline infectious peritonitis. Regulatory Mechanisms in Biosystems, 9(3), 460-468. doi: 10.15421/021869.

Kim, Y., Liu, H., Kankanamalage, A.C.G., Weerasekara, S., Hua, D.H., Groutas, W.C., Chang, K.-O., \& Pedersen, N.C. (2016). Reversal of the Progression of Fatal Coronavirus Infection in Cats by a Broad-Spectrum Coronavirus Protease Inhibitor. PLoS Pathogens, 12(3), e1005531. doi: 10.1371/journal.ppat.1005531.

Kipar, A., \& Meli, M.L. (2014). Feline Infectious Peritonitis: Still an Enigma? Veterinary Pathology, 51(2), 505-526. doi: 10.1177/0300985814522077.

Kipar, A., May, H., Menger, S., et al. (2005). Morphologic features and development of granulomatous vasculitis in feline infectious peritonitis. Vet Pathol, 42, 321-330.

Knotek, Z., Toman, M., \& Faldyna, M. (2000). Clinical and Immunological Characteristics of Cats Affected by Feline Infectious Peritonitis. Acta Veterinaria Brno, 69(1), 51-60. doi: 10.2754/avb200069010051.

Kotsan, I.Ya., Hrynchuk, V.O., Velemets, V.Kh., Shvarts, L.O., Pykaliuk, V.S. \& Shevchuk, T.Ia. (2009). Anatomiia liudyny [Human anatomy]. Tsentr uchbovoi literatury, Kyi'v (in Ukrainian).

Kudrjashov, A.A., \& Balabanova, V.I. (2011). Patologoanatomicheskaja diagnostika boleznej sobak i koshek [Pathological diagnosis of diseases of dogs and cats]. Institut veterinarnoj biologii, Sankt-Peterburg (in Russian).

Lucas, S.B. (2017). Lymph node pathology in infectious diseases. Diagnostic Histopathology, 23(9), 420-430. doi: 10.1016/j.mpdhp.2017.07.002.

Lucyk, O.D., Ivanova, A.J., Kabak, K.S., \& Chajkovs'kyj, Ju.B. (2003). Gistologija ljudyny [Human histology]. Knyga pljus, Kyi'v (in Ukrainian).

Merkulov, G.A. (1969). Kurs patologogystolohycheskoj tekhnyky [The course of pathohistological technique]. L.: Medycyna (in Russian).
Oliveira, L.B., Susta, L., Rech, R., et al. (2014). Pathology in practice. Effusive FIP with fibrinous epicarditis in a cat. J Am Vet Med Assoc, 245(8), 899-901. doi: 10.2460/javma.245.8.899.

Pedersen, N.C. (2014a). An update on feline infectious peritonitis: virology and immunopathogenesis. The Veterinary Journal, 201(2), 123-132. doi: 10.1016/j.tvj1.2014.04.017.

Pedersen, N.C. (2014b). An update on feline infectious peritonitis: Diagnostics and therapeutics. The Veterinary Journal, 201(2), 133-141. doi: 10.1016/ j.tvj1.2014.04.016.

Pedersen, N.C., Liu, H., Dodd, K.A., \& Pesavento, P.A. (2009). Significance of Coronavirus Mutants in Feces and Diseased Tissues of Cats Suffering from Feline Infectious Peritonitis. Viruses, 1(2), 166-184. doi: $10.3390 / \mathrm{v} 1020166$.

Pedersen, N.C., Liu, H., Durden, M., \& Lyons, L.A. (2016). Natural resistance to experimental feline infectious peritonitis virus infection is decreased rather than increased by positive genetic selection. Veterinary Immunology and Immunopathology, 171, 17-20. doi: 10.1016/j.vetimm.2016.01.002.

Pedersen, N.C., Liu, H., Gandolfi, B., \& Lyons, L.A. (2014). The influence of age and genetics on natural resistance to experimentally induced feline infectious peritonitis. Veterinary Immunology and Immunopathology, 162(1-2), 33-40. doi: 10.1016/j.vetimm.2014.09.001.

Pishak, V.P. (2008). Gistologija z osnovamy gistologichnoi' tehniky. Kyi'v: KONDOR (in Ukrainian).

Pyrs, Je. (1962). Gistohimyja [Histochemistry]. Izdatel'stvo inostrannoj literatury, Moskva (in Russian).

Rjemsi, Ja., \& Tennant, B. (2005). Infekcionnye bolezni sobak i koshek [Infectious diseases of dogs and cats]. Akvarium, Moskva (in Russian).

Rolim, V.M., Casagrande, R.A., Wouters, A.T., et al. (2016). Myocarditis caused by feline immunodeficiency virus in five cats with hypertrophic cardiomyopathy. J Comp Pathol, 154, 3-8. doi: 10.1016/j.jcpa.2015.10.180.

Uillard, M., Tvedten, G., \& Tornval'd, G. (2004). Laboratornaja diagnostika $\mathrm{v}$ klinike melkih domashnih zhivotnyh [Small Animal Clinical Diagnosis by Laboratory Methods]. Akvarium, Moskva (in Russian).

Urbanovych P.P., Potots'kyj, M.K., Gevkan, I.I., Zon, G.A. i in. (2008). Patologichna anatomija tvaryn. K.: Vetinform (in Ukrainian).

Vandevelde, K. (2015). Immunological barriers: Functional histology of the spleen. The Veterinary Journal, 205(1), 3-4. doi: 10.1016/j.tvj1.2015.04.033.

Ziółkowska, N., Paździor-Czapula, K., Lewczuk, B., Mikulska-Skupień, E., Przybylska-Gornowicz, B., Kwiecińska, K., \& Ziółkowski, H. (2017). Feline Infectious Peritonitis: Immunohistochemical Features of Ocular Inflammation and the Distribution of Viral Antigens in Structures of the Eye. Veterinary Pathology, 54(6), 933-944. doi: 10.1177/03009858177285. 